\title{
A oralidade na formação linguística do professor alfabetizador
}

\author{
Jilvania Lima dos Santos Bazzo*
}

\section{Resumo}

Ensinar a leitura e a escrita se constituem nos dois principais eixos norteadores da identidade do professor alfabetizador. Comumente, no ciclo de alfabetização, a linguagem oral é adotada como material físico para o trabalho de representação da escrita, sendo a reprodução da fala priorizada nesse processo em detrimento de seu patrimônio cultural. Ao problematizar esta questão, fundamentada numa perspectiva interacional, histórica e cultural da linguagem, neste artigo se discute sobre a cultura oral e a oralidade como objetos de trabalho e de pesquisa imprescindíveis para a formaçáo linguística do professor. Dessa forma, o que é oralidade? Quais as contribuiçóes dessa atividade social para alfabetizar uma criança? Qual o sentido e os efeitos de um processo de alfabetizaçáo que considera a oralidade imbricada ao ensino da produção textual oral, escrita e audiovisual? Conclui-se que ao ensinar as crianças a brincarem com textos, palavras, imagens e sons, o professor alfabetizador as ensina a cultivar e apreciar o belo, a beleza do encantamento, a fantasia e o estranhamento como elementos vigorosos para o aprendizado da humanizaçáo. Nesse processo, ele também as ensina a defenderem um posicionamento, quer seja escrito ou oral, a se sensibilizarem e a se colocarem de forma emancipada e criativa diante de qualquer problema ou desafio.

Palavras-chave: Alfabetização. Leitura. Linguagem Oral.

* Doutora em Educação pela Universidade Federal da Bahia (UFBA). Professora do Curso de Pedagogia da Universidade do Estado de Santa Catarina (UDESC). 


\section{Introdução ou algumas articulações necessárias}

[...] é a Literatura Tradicional a primeira a instalar-se na memória da criança. Ela representa o seu primeiro livro, antes mesmo da alfabetização, e o único, nos grupos sociais carecidos de letras.

Por esse caminho, recebe a infância a visão do mundo sentido, antes de explicado; do mundo ainda em estado mágico. Ainda mal acordada para a realidade da vida, é por essa ponte de sonho que a criança caminha, tonta do nascimento, na paisagem do seu próprio mistério. Essa pedagogia secular explica-lhe, em forma poética, fluida, com as incertezas táo sugestivas do empirismo, o ambiente que a rodeia - seus habitantes, seu comportamento, sua auréola. (MEIRELES, 1984, p. 83).

De fato, a vida não separa coisa alguma. Para compreender e operar com aquilo que está "naturalmente" misturado, nós dividimos, isolamos ou destacamos. É o que, a grosso modo, farei. Neste texto, há um esforço para que o viés poético e estético conduza a tessitura da narrativa. Para ativá-lo, isto é, provocar as características eminentemente humanas, faz-se premente concebê-lo na dinâmica da vida e das relaçóes sociais, tendo o indivíduo como ponto de partida e chegada em relação com o outro.

Em se tratando da alfabetização, nesse ponto de convergência entre escolarização e vida, demanda a criação de situações pedagógicas necessárias à materialização dessa dimensão poético-estética, ou seja, da vivência de experimentaçóes da ordem das sensaçóes, das percepçóes, das emoçóes, da imaginação, da fruição do belo, do encantamento e da beleza. É nesse contexto que a oralidade tomará acento e se destacará como aquilo que é o próprio processo dialógico, intenso e consolidado na relação $e u$-tu constituído por palavras misturadas a gestos, toques, sons, movimentos, imagens etc.

Cabe ressaltar que a matriz epistemológica assumida é aquela que entende a literatura como arte (BAZZO; CHAGAS, 2014) e a oralidade como prática cultural produzida pelas/nas relaçóes humanas, em tempos e espaços sociais específicos (VÓVIO, 2010). Isto significa que concebo essa produção cultural como um processo heterogêneo, complexo e plural; ao mesmo tempo em que conduzido por esse fio tênue, estético e poético, entendo que cada grupo 
humano compartilha, diante do uso da linguagem, suas normas, suas atitudes e seus traços linguísticos, os quais o distinguem dos demais grupos sociais.

Por se tratar de um dos papéis da escola que é fundamentalmente ensinar a ler e a escrever, abordarei a dimensão oral no imbricamento entre a produção escrita e a audiovisual. Neste entrecruzamento, a oralidade não diz respeito, por exemplo, à fala entre o bebê e seus familiares no processo inicial de apropriaçáo da linguagem. Discutirei, pois, sobre a dimensão oral no ciclo de alfabetização, isto é, na entrada da criança ao ensino formal da língua portuguesa nos três primeiros anos do Ensino Fundamental.

Importa, portanto, pensar sobre a oralidade como ponto de referência para o trabalho docente de forma indissociável da "Literatura Tradicional", mencionada por Cecília Meireles $(1984)^{1}$ como sendo o primeiro livro da criança. Como tal, a oralidade se constituirá como um objeto com dupla e indissociável função: ser condiçáo sine qua non para o ensino e para pesquisa e elemento principal para nortear a formação do professor alfabetizador. Sendo assim, o que é oralidade e quais são seus artefatos? Quais as contribuiçóes dessa atividade social para alfabetizar uma criança? Qual o sentido e os efeitos de um processo de alfabetização que considera a oralidade entrelaçada ao ensino do texto escrito e audiovisual que se vincula a esta "Literatura Tradicional"?

Com este trabalho, darei continuidade à divulgação das pesquisas que vêm sendo produzidas sobre a formação do pedagogo pelo Grupo de Estudos e Pesquisas Prolinguagem, da Universidade do Estado de Santa Catarina (UDESC), especificamente no que diz respeito à discussão acerca da oralidade no processo de formação do alfabetizador (ABREU; BAZZO; GODOY, 2013). Ao centralizar as reflexóes em torno da oralidade, tratarei, por certo, sobre alguns resultados teórico-práticos para nortear as atividades de ensino e aprendizagem com as crianças de 6 a 8 anos de idade.

É fato que ninguém questiona sobre a necessidade de se ensinar as crianças a leitura e a escrita. Entretanto, ainda hoje, não tem sido um consenso em relaçáo ao ensino da oralidade no processo de alfabetização, muito menos nessa relaçáo de interdependência com o acervo cultural oral (contos, parlendas, provérbios, adivinhas etc.). No máximo, os alfabetizadores propōem para as crianças atividades de transcrição e de reproduçáo fazendo uso de parlendas, provérbios e advinhas. Nesse tipo de proposição, o entrave é que, majoritariamente, se coloca a criança numa condição de assujeitamento e subordinação. Essas atividades se pautam na exigência exacerbada pela imitaçáo e pela repetiçáo de determinadas 
estruturas linguísticas, sem qualquer preocupação com as questôes de criação, imaginação, encantamento e fantasia - elementos caríssimos para o processo de aprendizagem da escrita e da leitura.

Infelizmente, acredita-se que as crianças aprendem a falar e a produzir discursos espontaneamente, que a apropriação da oralidade pela criança ocorre de forma assistemática e "natural" - como se a presença do outro fosse dispensável. A partir dessa visão, ignora-se que, nos espaços formativos primários, ou seja, na relação $e u-t u$, os seres humanos vão se constituindo. Embora não seja um ensino formal propriamente dito, há mediaçôes e aprendizagens. Considerando que a sociedade brasileira é grafocêntrica, ou seja, é centrada na escrita, a escola precisa compreender que o aprendizado da oralidade e da escrita precisa "caminhar" pari passu, especialmente porque dois aspectos estão aí implicados: os gêneros textuais/discursivos ${ }^{2}$ e os usos sociais que delas (da oralidade e da escrita) se fazem. Afinal, já se sabe que uma conversa entre amigos difere de outra entre colegas de trabalho - ainda que o conteúdo temático seja equivalente, o estilo e a construção composicional se alterarão.

Finalmente, por considerar as demandas atuais colocadas pelas práticas sociais de leitura e escrita, a oralidade será privilegiada no ciclo de alfabetização em face da sua capacidade transformadora - dos conhecimentos prévios das crianças aos conhecimentos científicos, tecnológicos, linguísticos, ambientais, filosóficos e artísticos a ser por elas utilizados/consumidos e produzidos de maneira autônoma, crítica, sensível, criativa e inventiva a um só tempo.

\section{Alfabetização: dos gêneros textuais à apropriação do sistema de escrita alfabético}

Parlendas, provérbios, adivinhas têm sido um pouco abandonados, na redação escrita, ligadas a jogos, brinquedos e outras práticas. Os provérbios tendem a desaparecer: é muito raro encontrá-los na conversação diária, a não ser entre pessoas bastante idosas. As adivinhas também vão escasseando, substituídas por outros entretenimentos.

Naturalmente, na província, onde a vida é mais vagarosa, todas essas formas de Literatura Tradicional têm mais probabilidade de durar. Mas nos grandes centros, 
onde ninguém mais conversa, onde poucos pensam e as liçóes da vida parece emanarem só do cinema e do rádio, sente-se a falta dessa sabedoria falada que é o ornamento do homem simples ${ }^{3}$, unido à natureza e aos seus antepassados. (MEIRELES, 1984, p. 88).

Aqui se inverte a lógica. Ao invés de se exigir primeiro da criança que ela reconheça as letras, aprenda a juntar sílabas, palavras e frases etc., ela aprenderá a ler e a escrever imersa em contextos de letramento, isto é, fazendo uso dos textos que circulam na sociedade, notadamente os textos da tradição oral. Por quê? Por ser uma "sabedoria falada que é o ornamento do homem" e que o une "à natureza e aos seus antepassados", a Literatura Tradicional (parlendas, provérbios, advinhas, causos etc.) poderá contribuir para o efetivo processo de reflexão sobre os seres humanos, sua relação com a natureza e com os pares. Enfim, ela favorecerá a conversação diária, conforme destacou Cecília Meireles (1984), no fragmento que abre esta sessão, ao mencionar que a conversa está cada vez mais escassa e que os aprendizados da vida parecem decorrer apenas do rádio e do cinema - também da internet, eu acrescentaria.

Aprendendo a fazer uso da leitura e da escrita, pelo diálogo, a criança compreenderá o funcionamento do sistema de escrita alfabético e entenderá as situaçóes e contextos de produção da linguagem (oral, escrita ou audiovisual), sobretudo, aprenderá a atribuir sentidos ao que lê e escreve, assim como perceber os efeitos de sentidos produzidos intencionalmente por textos produzidos por outras pessoas.

Com Magda Soares (2003, 2004) já se sabe sobre o significado da alfabetização no sentido lato e no sentido restrito. Embora indissociáveis e interdependentes, conforme pontua a autora, o processo de alfabetização pode ser interpretado, em sentido amplo, como o uso social que se faz da leitura e da escrita. Por outro lado, em sentido restrito, significa o aprendizado (sistemático e consciente) do sistema de escrita alfabético, o que envolve estudar a relaçáo entre fonema-grafema e grafema-fonema, dito de outro modo, trata-se do estudo acerca do funcionamento da língua portuguesa.

Significa, então, que o ensino deverá ser direto, explícito e sistemático de transferência da cadeia sonora da fala para a forma gráfica da escrita. Mas, o que é preciso evitar do ponto de vista didático-pedagógico? A repetição exacerbada, sem sentido para a criança, tal uma produção em série e automatizada. Significa 
ainda que é preciso que as crianças reconheçam, saibam produzir e "desenhar" as letras, conheçam seu valor sonoro e aprendam a explorá-las em contextos apropriados mediante situaçóes de uso concreto, de criação e invenção.

A alfabetização, portanto, diz respeito tanto ao processo de apropriação do sistema de escrita alfabético quanto à aprendizagem dos conhecimentos sobre as práticas, os usos e as funçóes da leitura e da escrita. Para que a criança se torne uma leitora/escritora autônoma, faz-se necessário ajudá-la a compreender os princípios que constituem o sistema alfabético por meio de reflexões sobre as relaçôes sonoras e gráficas das palavras. Nesse processo, ela precisa ser capaz de estabelecer as relaçôes entre som-grafia, entre letras e entre palavras. Indiscutível, pois, que a criança aprenda a dominar o sistema alfabético e ortográfico em contextos de letramento. Para tanto, o professor há de promover situaçóes de aprendizagem que promovam atividades sistemáticas de leitura e escrita explorando explicitamente as relaçóes existentes entre grafemas e fonemas, e vice-versa, assim como entre letras e entre palavras.

Na perspectiva de Soares (2004), a alfabetização no sentido restrito se torna insuficiente para ensinar uma criança a ler e a escrever. É preciso que se avance na direção de uma alfabetização no sentido lato, isto é, julga-se importante incorporar ao processo de aprendizagem do sistema de escrita as práticas sociais de leitura e escrita. Essa mudança de fluxo pedagógico provocará, sem dúvida, um trabalho interdisciplinar, que exigirá o envolvimento de todas as áreas do conhecimento. Desse modo, a alfabetização e o letramento ${ }^{4}$ se relacionam mutuamente e envolvem as vivências e as práticas culturais mais amplas de escrita e leitura.

Dessa forma, é consensual que há de se criar contextos significativos de aprendizagem. Para se ensinar as crianças, por exemplo, que, ao mudar a posição de uma letra de uma palavra $X$ qualquer, o sentido e o significado

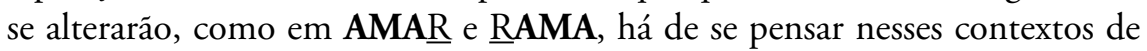
sentidos e significaçóes. Por que a palavra "amar" e não outra? Para quê? O que ela significa? Qual foi o contexto criado para possibilitar seu aparecimento e a necessidade de estudá-la? Quais leituras foram feitas? Quais histórias foram narradas? O que pensam as crianças sobre tal palavra? E que outras palavras podem ser produzidas (AMAR - AMOR - RAMA - ROMA - AMA - AMO - OMO etc)? Quais sentidos atribuídos? Que textos podem ser escritos com essas palavras? Para que e por que escrevemos? Essas e outras questôes podem ser os fios condutores da trama de sentidos produzidos com e pelas crianças. 
É certo que os estudantes precisarão também desenvolver a consciência de que há variações linguísticas a depender do grupo etário, étnico e/ou social, conforme as relaçóes e experiências histórico-culturais de cada um dos indivíduos. Em Porto Alegre, RS, por exemplo, "rabuda" significa "pessoa com sorte, sortuda", porém, no Rio de Janeiro se atribui outro sentido a essa palavra. O enunciado "É por aqui, madame!" evidencia quais contextos de produção e quais sujeitos envolvidos? Ou ainda, "A ave era rápida demais para eles. [...] ela pousava no topo de uma antiga mogobagôba sob a densa copa" (MANDELA, 2009, p. 11). A referência ao autor e a palavra mogobagôba revelam para o leitor que se trata de um texto pertence à cultura africana, ainda que ele não saiba que mogobagôba é uma "árvore nacional da África do Sul" (MANDELA, 2009, p. 151). De igual modo, se alguém afirma: - "Nunca usei vestido de alça. Gosto de usar saia e sempre usei rouge", logo se imagina o sujeito por trás desse discurso. Pode-se facilmente afirmar que seu locutor é uma pessoa do sexo feminino e idosa. Afinal, quem usaria saia, não gosta de vestido sem alça e usa rouge ao invés de blush? Esses exemplos, portanto, demonstram rapidamente as possibilidades de variação etária, étnica e/ou social da língua portuguesa.

Por conseguinte, para se aprender sobre a "mecânica" e o "funcionamento" da língua no contexto das variaçóes linguísticas, bem como operar sobre ela, é preciso saber ainda que os sentidos e os significados partilhados socialmente são produçóes textuais/discursos, são bens culturais, os quais compóem o conjunto de palavras interligadas entre si. Cada palavra, por sua vez, forma-se pelo encontro de letras, cujo valor sonoro será atribuído segundo sua posição na palavra e sua relação com outras letras. Como, por exemplo, a letra "C" diante de "A" ou "E" pode manifestar dois sons diferentes, /K/ ou /S/, como

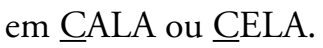

Tal qual a necessidade de contextualização para o estudo da posição dos numerais e suas alteraçóes de valor, assim serão com as letras. Suas posiçóes implicarão sentidos diferentes, porque os contextos e as situaçôes de interlocução exigirão. Nota-se, portanto, que, antes do trabalho com os valores assumidos pelas letras, importa o contexto criado com as crianças, que faça sentido para elas. Certamente, o processo dialógico instaurado entre as crianças e o professor alfabetizador produzirão os sentidos e as significações necessárias.

Embora os professores tenham ciência do conhecimento até aqui discutido, infelizmente, no ciclo de alfabetização, persiste uma dúvida em 
relação ao como se deve agir e $o$ que se deve fazer para que as crianças aprendam a produzir gêneros textuais orais em diferentes situaçóes de uso. Mais que isso, acredito que, em parte, essa dúvida persiste porque os alfabetizadores precisam compreender que os gêneros são também determinados pelo espaço social onde acontece a situação de interação, os tipos de relaçóes estabelecidas entre os interlocutores, os propósitos interativos e os papéis desempenhados pelos que participam da situação. É nesse processo que se fundamenta a concepção da alfabetização e de ensino da língua portuguesa, que se baseia no trabalho com os gêneros textuais/discursivos e que se circunscreve na proposta de letramento por considerar os usos sociais da leitura e da escrita.

As interações verbais como debates, contação de histórias, exposições orais, notícias radiofônicas, saraus, dentre outros, por se constituírem em práticas sociais relacionais (alunos-professor-alunos-alunos-professor), são comumente trabalhadas numa perspectiva não sistemática e sem o rigor pedagógico necessário. Para se promover as aprendizagens das crianças e as mudanças tanto no seu modo de estar-no-mundo e de se relacionar com outras pessoas quanto de pensar e agir no e sobre o mundo, há de se cuidar dos princípios éticos, estéticos, políticos e científicos nessa dimensão pedagógica relacional.

Outra dúvida refere-se à aprendizagem da argumentação e dos turnos de fala. Como ensinar as crianças a expor uma ideia e a defendê-la com argumentos que superem o meramente vivido ou conhecido? Como ensinar as crianças a ouvir, verdadeiramente, enquanto a outra fala - produz seu texto oral? Como fazer com que as crianças aprendam a viver coletivamente quando elas experimentam e (re)produzem exemplos similares aqueles da vida social fora dos muros escolares - de extremismo e violência de toda sorte?

Por serem questões contemporâneas, são relativamente compreensíveis os motivos que levam os alfabetizadores a terem dificuldades para encontrar alternativas e estratégias que ajudem as crianças a aprenderem a produzir textos orais - na perspectiva discursiva e de humanização ora empreendida. Sem dúvida, há uma vida que pulsa dentro e fora da instituição escolar, que torna o processo formativo ainda mais complexo, ainda mais difícil, especialmente porque, na grande maioria, as atuais ferramentas de comunicação e de informação são ignoradas. A seguir, serão apresentadas algumas reflexões em torno das práticas sociais de leitura e de escrita articuladas ao contexto teórico-metodológico das tecnologias digitais em sala de aula. 


\section{Alfabetização: práticas sociais de leitura e escrita em tramas semióticas}

Dentro da subversão, palpitam infâncias: infâncias que assistem de olhos assombrados cenas que nenhum autor se atreveria a contar-lhes. Cenas vivas e vividas - não escritas. Se o que se lê não se esquece, como se esquecerá o que se vê??

$\mathrm{E}$ as crianças veem, dia a dia, nestes angustiosos tempos, as mais trágicas histórias. Veem-nas nas fotografias das revistas e jornais, na tela dos cinemas; ouvem-nas em descrições de rádio, nas conversas dos adultos, a cada instante, por toda parte... (MEIRELES, 1984, p. 134).

Ao revisitar a história da alfabetização no Brasil (MORTATTI, 2006), na busca pela compreensão dos enfrentamentos teóricos e práticos dos alfabetizadores, em parte já discutidos anteriormente, bem como pela necessidade de um ensino pautado nos gêneros textuais/discursivos, observase que até mais ou menos início da década de 1980, havia uma preocupação excessiva na memorização e na repetição de padrôes linguísticos. As crianças, por sua vez, vivenciavam atitudes monológicas, de subserviência e nada criativas.

Nesses contextos de subordinação, as crianças iam se constituindo enquanto reprodutoras tanto dos discursos quanto dos modos de se relacionar. Textos artificiais e encomendados para o trabalho de aprendizagem da escrita, concebida como código, vinculavam a palavra a uma determinada estrutura frasal, descolando-a do contexto de produção e de interlocução e ignorando, portanto, a escrita como sistema representacional, simbólico. Havia, por isso, nenhuma ou pouquíssima preocupação com os interlocutores. Tal estreiteza de concepção sobre língua(gem) desconhece (ou desconheceu) o processo de leitura e escrita das crianças imbricado ao estar-no-mundo como agentes sociais ativos, históricos, produtores culturais, que mobilizam gêneros, mídias e linguagens (ROJO; MOURA, 2012).

Por outro lado, concebida como um processo de aprendizagem do sistema alfabético e ortográfico mediante o uso efetivo da língua em práticas sociais de leitura e escrita (SOARES, 2003, 2004), a concepção atual de alfabetização reconhece a multiplicidade cultural das populaçóes e a multiplicidade semiótica de constituição de textos por meio dos quais as crianças se informam e se 
comunicam. Reconhece-se ainda que, mediadas por uma trama semiótica complexa, elas estabelecem sentidos, provocam relaçóes comunicativas e participam ativamente do processo de constituiçáo de suas identidades e pertencimentos.

Essas tramas, de acordo com Santaella (2004), se efetivam não somente por meio da linguagem verbal, mas, também, por meio de interaçóes de forças, movimentos, gestos, expressóes, sons musicais, luzes, cheiro, tato, olhar, sentir e apalpar, e por meio de objetos diversos, formas, volumes, massas, dimensôes e direçóes de linhas, imagens, gráficos, sinais, setas e números. Para a autora, há um "novo" leitor em cena, o qual ela concebe como aquele que ultrapassa os limites, exclusivamente, dos elementos verbais. Segundo Santaella (2012), cada vez mais, a escrita se une à imagem, ao som e ao movimento, o que exige superação de uma perspectiva de leitura/escrita ligada apenas ao processo de decifração de letras do enunciado verbal.

No bojo desse debate, e na tentativa de buscar superar a concepção de alfabetização dissociada da vida prática e social, os profissionais da educação vêm num crescente esforço para realizar um trabalho pedagógico que priorize o uso da língua oral, escrita e audiovisual inserindo as crianças em práticas revolucionárias de letramento. O que isso significa?

De acordo com Kleiman (1995, p. 19), letramento é um “conjunto de práticas sociais que usam a escrita, enquanto sistema simbólico e enquanto tecnologia, em contextos específicos, para objetivos específicos”. Conforme Barton (2007), as práticas de letramento seriam as maneiras pelas quais cada cultura utiliza a escrita, práticas nas quais os indivíduos se baseiam quando participam de um evento de letramento, isto é, quando participam de uma atividade humana em que a escrita está presente. Para este autor, a escrita desempenha funçôes distintas na vida diária dos indivíduos, constituindo eventos de letramento de todo tipo, fenômeno esse caracterizado pelas açóes em que a leitura e a escrita fazem parte. Por exemplo, um diálogo entre dois jovens sobre os filmes a serem exibidos no cinema no próximo final de semana, por meio de folhetos ou folders distribuídos na sua comunidade ou a narração de uma história fazendo remissão à obra escrita se constitui momentos diferenciados do uso social da escrita/leitura.

Ainda segundo Barton (2007), as práticas de letramento, por sua vez, são os valores atribuídos a esses eventos, o que tem uma ancoragem social, cultural e histórica. As práticas sustentam os eventos, afirma o autor. Ler um conto, por 
exemplo, é um evento de letramento que pode estar ancorado em diferentes práticas. Se o professor alfabetizador, em classe, encaminha a leitura de um dos contos selecionados por Nelson Mandela (2009), por exemplo, esse evento de letramento seguramente terá ancoragem em diferentes práticas de letramento, porque seu "resultado" dependerá de quem sejam seus alunos.

Se os alunos viverem em entornos familiares em que ler livros ou contar histórias é um comportamento comum e valorizado, eles estarão ancorando a leitura, por exemplo, do conto "A encantadora canção do Pássaro Mágico5" de um modo específico, estabelecerão relações e produzirão tantas narrativas forem necessárias. Se viverem em entornos familiares em que a leitura de livros é um comportamento excepcional e pouco valorizado, os estudantes tendem a ancorar esse evento de letramento em práticas de pouca valorização. De modo semelhante, a qualidade da mediação (e da relação) estará subordinada à competência profissional do alfabetizador e ao seu repertório histórico e cultural. Nesse sentido, aumenta ainda mais a responsabilidade da instituição escolar no desenvolvimento de valores e hábitos relacionados a essas práticas de letramento e, sobretudo, no investimento da formação continuada (em serviço) do professor alfabetizador.

A partir desse entendimento, está claro que o letramento diz respeito aos usos sociais da escrita caracterizados pelas diferentes formas de interação humana e pela variedade cultural e histórica de cada um dos implicados nessa prática social. Considerando que tais interaçóes são múltiplas, por conta da diversidade de gêneros textuais/discursivos, mídias e linguagens, em razão de especificidades culturais e históricas, os usos da escrita se revelam de formas distintas, atendendo a demandas de diferentes grupos humanos. Portanto, as práticas de letramento se diferenciarão em cada comunidade, evidenciarão e repercutirão o modo como os indivíduos concebem e efetivam os eventos de letramento.

$\mathrm{O}$ que as crianças fazem com a escrita nos entornos sociais e culturais que deles participam - para quais finalidades a escrita serve em suas vidas diárias? Para Mendes (2009, p. 114), o grupo cultural ao qual a criança pertence constitui forte influência no seu desenvolvimento (cognitivo, afetivo, moral e social), que está condicionado às interaçóes "com as formas culturais as quais a criança está exposta, ou seja, sua experiência com os adultos do grupo, sua experiência com a linguagem e suas formas de expressão e representação". A autora acrescenta a esse processo o modo particular como cada criança interage com seu entorno e a singularidade de suas atitudes e comportamento frente às 
experiências. Por isso é de suma importância observar como as crianças lidam com a escrita, suas produçóes e interaçôes sociais.

Em que medida os professores alfabetizadores estão atentos, recepcionam e estabelecem um diálogo entre as práticas de letramento das crianças e aquelas a serem agenciadas pela escola a fim de ampliar seus repertórios culturais artísticos, linguísticos, científicos, tecnológicos e ambientais? Quais são as práticas sociais de letramento promovidas pela/na escola para desafiar as crianças em seu processo de aprendizagem?

Cada um em particular (e cada comunidade em geral) usa de modo diferente a língua escrita, dependendo de onde viva, de quem seja, naquilo com que se ocupa. Há demandas relativas ao pertencimento cultural e à inserção social envolvidas nesses usos. Afinal, como tão bem pontuou Cecília Meireles (1984), as crianças 'veem' cenas vivas e vividas em diferentes contextos: nas fotografias, nos jornais, nas revistas, nas telas do cinema, e 'ouvem' nas descriçốes de rádio e nas conversas dos adultos as mais trágicas histórias. Essas questóes precisam ser uma das preocupaçóes do alfabetizador para qualificar ainda mais seu trabalho como um dos principais profissionais responsáveis pelo ensino da língua portuguesa. Sem dúvida, o professor deverá efetuar a potenciação da consciência comunicativa dos alunos exatamente para que eles consigam ser utilizadores/consumidores críticos e conscientes de rádio, cinema, internet $\mathrm{e}$ das mídias em geral.

\section{A oralidade e a cultura oral no processo de alfabetização}

O gosto de contar é idêntico ao de escrever - e os primeiros narradores são os antepassados anônimos de todos os escritores. O gosto de ouvir é como o gosto de ler. (MEIRELES, 1984, p. 49).

De acordo com Bagno (2011), no mundo há cerca de três quartos de línguas ágrafas, ou seja, aquelas nas quais são faladas ou gesticuladas, a exemplo das línguas Xavante, falada por índios brasileiros, e Changana, falada em Moçambique. Nessas línguas é redundante afirmar que há um acervo cultural imenso de tradição oral, como causos, histórias, saberes e conhecimentos, que são passados de geração a geração. Caso distinto, como já sabemos, do nosso país, cuja língua oficial é gráfica e cujo sistema é alfabético - a língua portuguesa. 
Observando o processo de constituição do povo brasileiro, há em sua matriz um abundante acervo cultural de tradição oral que pode auxiliar os professores alfabetizadores a compreenderem a diversidade da língua portuguesa do Brasil. E mais, pode ser uma fonte inesgotável de pesquisa e levantamento de possibilidades pedagógicas a ponto de, por exemplo, superar atividades estereotipadas com usos recorrentes da personagem "Chico Bento", criado pelo cartunista brasileiro Maurício de Sousa, para tratar de questóes relacionadas às variaçóes linguísticas. Nada contra a obra ou o autor. Pelo contrário, esse exercício de superação zela, inclusive, pelo vigor de cambos.

Diante dos textos de tradição oral, a exemplo das advinhas e parlendas, como o alfabetizador deverá se posicionar para dar conta de ensinar a ler e a escrever potencializando-os ainda mais? Quais as tecnologias disponíveis que poderão auxiliar o professor nessa tarefa? Seria possível, por exemplo, o uso adequado das tecnologias da informação e da comunicação (TIC) nesse processo? Como se daria a retextualização de um texto oral para uma produção, diria híbrida, envolvendo a língua escrita e audiovisual?

No livro Pelas ruas da oralidade: advinhas, perlendas, trava-linguas, provérbios e trancoso, Gomes e Ferreira (2006) apresentam cada um desses gêneros textuais, o que ajuda a refletir sobre formas diversas de retextualização, isto é, "traduzir" uma modalidade (oral) para outra (escrita), permanecendo na mesma língua, a exemplo de uma entrevista oral para a produçáo de uma reportagem jornalística. Em atividades dessa natureza, os professores podem propor aos estudantes a produção de textos híbridos e que se façam uso de tecnologias da comunicação e da informação.

No exemplo anterior, ao produzir a reportagem, as crianças podem escrevê-la para publicá-la num blog ou numa rede social, planejada especificamente para essa finalidade. A entrevista oral poderá ser filmada ou gravada em áudio para, posteriormente, ser editada e publicada. Pode-se ainda produzir um vídeo mesclando imagens, músicas, trechos da entrevista oral ou escrita, trechos da reportagem jornalística. Que fique bem claro: no processo de alfabetização, as crianças precisam de exercícios criativos que instiguem a imaginaçáo, a fantasia e a curiosidade, sobretudo, explorem outros espaços sociais e as desafiem constantemente. As tecnologias digitais podem e devem ser incorporadas às práticas escolares no ciclo de alfabetização, especialmente porque favorecerão a busca por outros leitores que não somente o professor. Escrever para leitores diferentes se constituirá 
num desafio bastante instigante para as crianças, certamente também para a professora no momento de ensiná-las a pensar sobre o quê, por que e para quem escrever.

Nesse movimento, mais do que simplesmente "aprender a falar" (usar determinados gêneros) ou "traduzir" um texto oral para um escrito, que fique bem claro: as crianças precisam ler e produzir textos de modo emancipado e inventivo. É importante também ressaltar que, por ser uma prática social, a oralidade se situa no plano das interaçôes. Há, dessa maneira, uma dimensão dialógica, uma exigência pela relação eu-tu/eu-outro. Por ser um modo de manifestação/representação da língua, no aprendizado da fala em contextos diversificados, é preciso também aprender a ouvir o outro, aprender a fazer uso da pausa, aprender a respirar, aprender a olhar com atenção, interessar-se pelo assunto abordado, ente outras aprendizagens.

No processo de oralização da palavra escrita, isto é, quando uma criança ou um adulto ler para as demais pessoas, há ainda um enorme potencial para efetivação de tais aprendizagens. Poderíamos dizer que, no momento em que ocorre a oralização da escrita, se estabelece uma relação de cumplicidade para a compreensão daquilo que se ler, inicia-se, assim, um intenso processo de alfabetização, no sentido lato do termo - já problematizado nos tópicos anteriores.

Percival de Leme Britto (2012), ao discutir sobre o aprendizado da leitura e da escrita na idade pré-escolar das crianças, destaca a importância da "leitura pelos olhos alheios". O que isso significa? Geralmente, atribui-se a competência leitora apenas para aqueles que sabem "traduzir em palavras" o texto escrito para o oral. Existe aí uma leitura que implica em dois movimentos distintos e complementares: o de uma "traduçáo" do escrito para o oral e o de uma leitura feito pelos ouvidos e os olhos atentos na cena, na relação $e u-t u$, enfim, existe aí uma forma atenta de escuta/leitura.

Já temos ciência que as crianças tendem a desenvolver a criatividade, a fantasia e a imaginação mediante inserçôes em contextos de letramento, isto é, espaços de circulação do texto escrito. Porém, não basta apenas ler e escrever como atividades meramente corriqueiras. É preciso, antes de tudo, ter competência para selecionar textos que sejam capazes de contribuir para a mudança de conduta, de forma de ver e se relacionar com o mundo. Importa, assim, saber o que fazer com o texto lido ou produzido, seja qual for o gênero textual/discursivo. 
Outro aspecto tão fundamental quanto ter uma postura ativa frente ao texto diz respeito à incorporação nas "conversas cotidianas" com as crianças das leituras realizadas. De fato, trata-se de um diálogo com intencionalidade bem traçada, propondo desafios às crianças em relação ao conhecimento estudado e produzido com vistas à ampliação do seu repertório histórico e cultural. Óbvio, mais do que ampliar repertório, que seja capaz de contribuir para essa utopia transformadora de mudanças históricas e culturais: seres humanos altivos, inventivos, sensíveis.

Além desse processo dialógico, a leitura também se refere ao ato de ler para si mesmo(a). Cláudia Vóvio (2010, p. 402), ao apresentar esses dois posicionamentos sobre a leitura, "a leitura/ato solitário - você e o livro -" e "a leitura/momento de diálogo", ajuda-nos a compreender que, no ciclo de alfabetização, terão de ser oportunizadas situaçôes de aprendizagem abrangendo um e outro processo. Para aprender a identificar as letras e realizar a leitura, as crianças precisam aprender a pegar um livro (ou qualquer outro aporte textual, como o jornal, a revista, encarte publicitário, entre outros), familiarizar-se com esse objeto cultural, saber que existem espaços entre as palavras e entre os parágrafos. Se houver imagens e outros signos extralinguísticos, elas precisam compreender que esses elementos presentes no texto ajudam a compreendê-lo e a refletir sobre o assunto e as questóes ali implicadas.

Por estar estritamente relacionada à oralidade e trazer em primeiro plano a relação entre as crianças e o professor, a segunda concepção (leitura/momento de diálogo) torna-se o vetor que canalizará para outras experimentaçóes, tanto na leitura quanto na produção de textos (escritos, orais e/ou audiovisuais).

\section{Considerações finais}

A partir dos estudos aqui empreendidos, reunir argumentos que evidenciassem a necessidade de investimento na formação linguística do professor alfabetizador, sobretudo nas questôes implicadas à oralidade e à cultura oral, incluindo essa modalidade da língua como objeto de ensino e pesquisa. É preciso que os cursos de Pedagogia insiram nos seus currículos a língua(gem) oral, compreendida não apenas na dimensão da fala, dos traços eminentemente linguísticos, mas, especialmente, na sua produção histórica e cultural.

Durante a tessitura textual, conceituei oralidade e apresentei seus principais artefatos - os textos de tradição literária, concebido pela Cecília 
Meireles (1984) como sendo o acervo da Literatura Tradicional: parlendas, adivinhas, contos entre outros. Destaquei as contribuiçóes dessa atividade social para alfabetizar uma criança, especialmente pelo seu caráter emancipatório e inventivo. Nele, há um esforço em mostrar o sentido e os efeitos de um processo de alfabetização que considera a oralidade entrelaçada ao ensino do texto escrito e audiovisual que se vincula a esta abordagem.

Para além da criação de "espaços e tempos" para as crianças falarem e se expressarem, busquei também demonstrar o quão necessário se faz zelar pela qualidade dos contextos disponibilizados e dos textos (orais e escritos) a serem partilhados com e pelas crianças. Há de se incorporar ainda nos diálogos cotidianos com os alunos as leituras realizadas, relacionando-as ao movimento vivido e vivente.

Nesse processo dialógico, há de acionar as palavras lidas e de garantir que as crianças possam, ao produzir sentidos, experimentar a invenção e a criação de outras palavras. Para isso, o professor precisa saber sobre o que, por que para que e como perguntar. Além disso, não basta apenas que o grupo compreenda as diferenças entre uma conversa entre amigos e uma discussão teórica, por exemplo. Sem dúvida, aprender a falar e a ouvir no coletivo e em espaços formais, não íntimos ou familiares, constitui-se uma necessidade basilar. Para tanto, o acervo cultural disponível de textos orais precisam ser explorados e incorporados à prática docente.

Diante do exposto, é certo afirmar que para o trabalho com a língua(gem) oral há de se pensar que a oralidade envolve ter objetivos claros. $\mathrm{O}$ que isto significa? Que é preciso saber aonde se quer chegar, com quais estratégias se trabalhará para criar as condiçóes necessárias para os estudantes desenvolverem a competência comunicativa, crítica, interacional e dialógica. Sendo assim, torna-se premente investir nas suas singularidades da criança, cuja subjetividade deve ser pensada de forma indissociável do coletivo, ativando diferentes saberes e experiências curriculares, que a respeitem em sua diversidade e pluralidade históricas e culturais.

\section{Notas}

${ }^{1}$ Trata-se de uma obra que, publicada em 1951, foi resultante de um ciclo de conferências para professores proferidas em 1949, em Belo Horizonte, MG. De acordo com Isis Cristina Ramanzini (2014), Cecília Meireles 
buscava superar a concepção moral, instrutiva e recreativa em voga nos livros de literatura destinados às crianças.

${ }^{2}$ Os gêneros textuais/discursivos são instrumentos culturais, que se materializam em textos que os seres humanos produzem para interagir na sociedade bem como nas situaçóes de aprendizagem na escola.

${ }^{3}$ Há notadamente, com este conceito "homem simples", uma intenção de colocar em evidência a cultura oral, por reconhecer em algumas comunidades ágrafas a pujança dessa cultura. Historicamente, com o estereótipo do sujeito não escolarizado e vivendo de uma transmissão cultural oral, a escola tem criado superficialidades e impedido que as crianças vivenciem contextos e situaçóes efetivas de aprendizagem da língua oral.

${ }^{4}$ Discute-se, no terceiro tópico deste trabalho, sobre o letramento como campo do conhecimento que investiga as práticas sociais de uso da escrita (KLEIMAN, 1995).

${ }^{5}$ Selecionado por Nelson Mandela (2009) e registrado no início do século XX na Tanzânia pelo Pastor Julius Oelke da Igreja da Missão de Berlim, este conto é sobre um pássaro que destruía todo e qualquer tipo de alimento de uma pequena aldeia. Ninguém conseguia detê-lo. Certo dia, o líder dos aldeóes solicitou que os homens mais velhos afiassem seus machados e facóes e atacassem o pássaro. Mas, eles fracassaram. Assim que iniciaram o trabalho, uma canção ecoou da garganta do pássaro e os homens mais velhos ficaram táo emocionados e encantados com a beleza da ave que se negaram a destruí-lo. O chefe tribal, então, convocou os jovens para eliminar o poder do pássaro, porém, pelas mesmas razóes do grupo anterior, eles não conseguiram aniquilá-lo. Finalmente, ele convidou as crianças para realizar o que os outros não haviam conseguido. Como olhavam fixos para seus machados e facóes e seus ouvidos só podiam ouvir o som repetitivo desses instrumentos, as crianças conseguiram executar a missão. Para recompensá-las, o chefe anunciou uma grande festa e afirmou que elas eram as únicas que ouviam verdadeiramente e enxergavam com clareza. 


\section{REFERÊNCIAS}

ABREU, Geysa Spitz Alcoforado de; BAZZO, Jilvania Lima dos Santos; GODOY, Dalva Maria Alves. O ensino da língua materna nos currículos dos cursos de Pedagogia. Revista de Educação, Campinas, SP, v. 18, n. 3, 2013. BAGNO, Marcos. Gramática pedagógica do português brasileiro. São Paulo: Parábola, 2011.

BARTON, David. Literacy: an introduction to the ecology of written language. Cambridge: Brackwell, 2007.

BAZZO, Jilvania Lima dos Santos; CHAGAS, Lilane Maria Moura. Leitura de fruição no programa nacional de alfabetização na idade certa no Estado de Santa Catarina. Revista Linha Mestra, Campinas, SP, ano 8, n. 24, p. 144162, jan./jul. 2014.

BRITTO, Percival de Leme. Inquietudes e desacordos: a leitura além do óbvio. Campinas, SP: Mercado de Letras, 2012.

GOMES Lenice; FERREIRA, Hugo Monteiro. Pelas ruas da oralidade: advinhas, parlendas, trava-línguas, provérbios e trancoso. 2. ed. São Paulo: Paulinas, 2006.

KLEIMAN, Angela (Org.) Os significados do letramento: uma nova perspectiva sobre a prática social da escrita. Campinas, SP: Mercado de Letras, 1995.

MANDELA, Nelson. Meus contos africanos. Tradução Luciana Garcia. São Paulo: Martins Fontes, 2009.

MEIRELES, Cecília. Problemas da literatura infantil. 3. ed. Rio de Janeiro: Nova Fronteira, 1984.

MENDES, Angelita. Implicaçóes da cultura grafocêntrica na apropriação da escrita e da leitura em dois diferentes contextos. 2009. $161 \mathrm{f}$. Tese (Doutorado em Educação) - Universidade de São Paulo, São Paulo, 2009.

MORTATTI, Maria do Rosário Longo. História dos métodos de alfabetização no Brasil. In: SEMINÁRIO ALFABETIZAÇÃO E LETRAMENTO EM DEBATE, 2006, Brasília. Anais... Brasília, DF: MEC, 2006. Disponível em: <http://portal.mec.gov.br/seb/arquivos/pdf/Ensfund/ alf_mortattihisttextalfbbr.pdf>. Acesso: 6 jan. 2014. 
RAMANZINI, Isis Cristina. Paratopia criadora: Cecília Meireles, uma escritora atuante no cenário educacional.Revista l@el em (dis-)curso, São Paulo, v. 6, n. 2, 2014.

ROJO, Roxane; MOURA, Eduardo. Multiletramentos na escola. São Paulo: Parábola, 2012.

SANTAELLA, Lucia. Comunicação e semiótica. São Paulo: Hacker, 2004. SANTAELLA, Lucia. Leitura de imagens. São Paulo: Melhoramentos, 2012. (Coleção Como eu ensino).

SOARES, Magda. Alfabetização e letramento. São Paulo: Contexto, 2003. SOARES, Magda. Alfabetização e letramento: caminho e descaminhos. Revista Pátio, Porto Alegre, ano 7, n. 29, fev./abr. 2004.

VÓVIO, Claudia Lemos. Discursos sobre a leitura: entre a unidade e a pluralidade. Perspectiva, Florianópolis, SC, v. 28, n. 2, p. 401-431, jul./dez. 2010. 


\section{La oralidad en la formación lingüística del maestro alfabetizador}

\section{The orality in linguistic teaching training of the literacy teacher}

\section{Résumé}

Enseñar la lectura y la escritura constituye dos de los principales ejes rectores de la identidad del maestro de alfabetización. Comúnmente, el ciclo de la alfabetización, el lenguaje oral es adoptado como material físico para el trabajo de la representación de la escrita, siendo la reproducción del discurso una prioridad en este proceso en detrimento de su patrimonio cultural. Para abordar este tema, basado en una perspectiva interactiva, histórica y cultural del lenguaje, en este artículo se analiza la cultura oral y la tradición oral como objetos de trabajo e investigación esencial para la formación del profesorado de idiomas. Así, nos preguntamos, ¿Cuál es lenguaje oral? ¿Cuáles son las contribuciones de esta actividad social para alfabetizar a un nińo? ¿Cuál es el sentido y los efectos de un proceso de alfabetización que considera la enseñanza oral imbricada de producción de textos orales, escritos y audiovisuales? Llegamos a la conclusión de que cuando el maestro de los primeros años de la educación primaria enseña a los niños a jugar con textos, palabras, imágenes y sonidos, ellos enseñan a cultivar y disfrutar de la belleza, del encanto, la fantasía y la extrañeza como elementos vigorosos para el aprendizaje de la humanización. En este proceso, también se les enseña

\section{Abstract}

Reading and writing skills are the literacy teacher's guiding principles. Commonly, in the literacy cycle, oral language is adopted as a physical material to represent the written work and it has been prioritized in this process due to its cultural heritage. To discuss this issue which is based in a interactional, historical and cultural perspective, the oral culture and orality are discussed in this article as being essential work and research objects to the teacher's linguistic training. In this way, we make some questions: What is orality? What are the contributions of this social activity to teach a child to read and write? What is the meaning and the effects of a literacy process that considers the orality imbricated to the oral text production, written and audio visual language teaching? One may conclude that when children are taught how to play with texts, words and images by the literacy teacher, he teaches them how to admire and cultivate the beautiful, the beauty of being enchanted, the fantasy and strangeness as vigorous elements to humanization learning. In this process, he also teaches children to defend an oral or written idea, to raise awareness, and to put themselves in an empowered 
a defender un posicionamiento, ya sea de forma escrita u oral, y a colocarse de manera autónoma y creativa frente a cualquier problema o desafío que se les presente.

Palabras-clave: Alfabetización. Lectura. Lenguaje oral. and creative way in case of facing any problem or challenge.

Keywords: Literacy. Reading. Oral language.

\section{Jilvania Lima dos Santos Bazzo}

E-mail: jilvaniabazzo@gmail.com

Enviado em: 1/6/2014 Aprovado em: 20/12/2014 